prevalent in Central Europe than in the west. Soldiers, however, are not the only persons liable to contract the disease, although they were chiefly affected during the Great War, but owing to the contacts between the army and the civil population the latter are also liable to become infected, especially in the case of large agglomerations and refugees. Although trench fever is not a serious disease in itself, it may be the cause of a considerable degree of invalidism, as is shown by the fact that Sir Wilmot Herringham calculated at eight million the total number of days off duty in the British Army due to this cause. Prevention consists in immediate isolation of the first cases, delousing of contacts and other methods for the destruction of lice.

\section{Miniature Circuit-Breakers}

THE Electrical Review of March 29 points out that an amendment has been made by the Standards Association of Australia to its wiring rules, by a provision that the loading of final sub-circuits may be increased if sealed circuit-breakers of an approved type are used in place of fuses. In this case two general purpose socket outlets in a room of a dwellinghouse can be counted as one if connected with an 8,12 or 18 ampere final sub-circuit, and any permanently connected appliance rated at 100 watts or less may be counted as a lighting point. It is stated that in many cases the additional cost of the circuitbreaker will be largely offset by the reduction in the number of fuses required. While the Wiring Rules of the Standards Association of Australia differ materially from the Regulations of the Institution of Electrical Engineers, thus precluding the possibility of direct comparison, the value of a circuitbreaker the setting of which cannot be tampered with would in many cases be high.

\section{The Science Masters' Association}

The report for 1939 of the Science Masters' Association records a rapid growth in membership. Last year no fewer than 914 schools were represented, whereas twenty years ago there were only 143. So extensive a combination can produce effective action, which we notice in the first annual report of the London and Home Counties Branch. Suggestions on the new physics syllabus of the London General School Examination were made after discussion, sent to the general committee of the Association, passed on, and accepted. The result is changes which are announced to "take effect in the physics paper at the next examination".

\section{Memorandum on Scabies}

SCABIES, or the 'itch', is a superfieial inflammation of the skin caused by infestation with the itch mite, the female of which burrows into the skin producing much irritation. The affection is very liable to occur among collections of persons living together in restricted circumstances such as are met with in wartime, among evacuee children, soldiers and others. The Ministry of Health has therefore issued a useful memorandum on the subject (Memo. 229/Med. H.M. Stationery Office. $2 d$, net). It describes the affection and its complications, diagnosis, methods of spread and prevention, and the treatment.

\section{The Iron and Steel Institute}

Mr. John CraIG, ehairman and managing director of Messrs. Colvilles, Ltd., has been elected president of the Iron and Steel Institute for the next two years. Mr. Craig will be inducted into the presidential chair by the retiring president, Lord Dudley, at the annual general meeting on May 2. The Bessemer Gold Medal for 1940 of the Institute has been awarded to Dr. Andrew McCance, of Glasgow, in recognition of his eminent services in connexion with the application of science to the iron and steel industry. Dr. McCance is a director and general manager of Messrs. Colvilles, Ltd. M. Eugène Schneider has been nomin. ated an honorary member to celebrate the fiftieth anniversary of his election to membership. M. Schneider joined the Institute in 1890 and was president for the period 1918-20. An Andrew Carnegie Silver Medal has been awarded to Mr. Bo W. L. Ljunggren for his memoir entitled "Method of Sclero-grating employed for the Study of Grain Boundaries and of Nitrided Cases ; Grain Structures revealed by Cutting". The Williams Prize for 1939 has been divided between Mr. W. B. Lawrie, for his paper on "The Refining of Metal in the Basic Open-Hearth Furnace. The Influence of Fluorspar on the Process", and Mr. W. T. Wilson, for his paper on "The Rolling of Sections at the Appleby-Frodingham Steel Company, Limited." No papers have been received in competition for the Ablett Prize for a paper on a subject connected with engineering in iron and steel works written by a junior engineer. Captain Ablett has renewed the offer of the Prize for competition in 1941. Particulars can be obtained from the Secretary of the Institute; papers must be submitted not later than January 31, 1941.

\section{Announcements}

THE annual joint meeting of the Institute of Radio Engineers and the American Section of the International Scientific Radio Union will bo held at the National Academy of Sciences, Washington, D.C., on April 26. A programme of abstracts will be available in booklet form about April 15. Correspondence should be addressed to S. S. Kirby, National Bureau of Standards, Washington, D.C.

A RESEARCH department for racial hygiene has recently been created in the Welfare Ministry in Japan. It is preparing a new law on marriage and sterilization.

According to the United States National Healtli Survey the prevalence of blindness is greater among men than among women. For every one hundred blind women, one hundred and eleven men were affected. Nearly twice as much blindness was found among coloured people as among white. 